\title{
Networks of Social Justice: Transnational Activism and Social Change
}

\author{
SUZAN ILCAN
}

University of Waterloo, Canada

ANITA LACEY

The University of Auckland, New Zealand

Transnational activism is broad in scope and scale and underscores forms of activism and struggles that operate within, across, and beyond the state. We understand the term transnational activism to designate a range of synchronized cross-border activities, campaigns, and movements on the part of networks of activists working counter to various state actors, international actors, or international institutions. It includes a diverse array of participants engaging in activist networks - from those working in local and regional groups to those associated with national and international organizationswith the aim of bringing about social, economic, and political change across borders.

Over the past several decades, the establishment of transnational forms of activism has emerged in response to themes relating to interventions by states and international actors around issues ranging from the privatization and commodification of land, to neo-colonial and imperial processes of the appropriation of assets, to gender, sexuality, class, and race relations, to undocumented migrants, border control, and immigration policies, to human and citizenship rights. In many spaces and places around the globe, we can identify several transnational forms of activism. There are grassroots activist groups and movements that operate in local and national circles and that have a transnational reach, and aim to bring awareness to issues of social injustice. We may think here, for example, of the global days of action in Seattle, Genoa, Gleneagles, and elsewhere against neoliberal institutions and state governments (see Gill, 2000; Klein 2002; Routledge \& Cumbers, 2009), the formation of the World Social Forum and numerous regional forums, the antiFree Trade Agreement activisms waged in widely varied locales like South Korea, Ecuador, and Thailand, and the diversity, scale, and significance of 
the Arab Spring movement and other activist movements such as the Global Justice Movement and the Zapatista movement.

The Global Justice Movement is a transnational movement of grassroots activists and organized advocacy groups working for global justice on economic, social, political, and environmental levels, and working against the neoliberal model of international development and the policies of the states and international institutions that advance it (Hadden \& Tarrow, 2007, p. 215). It can be traced back to the international movements of the 1970s and 1980s relating to such social justice issues as peace, human rights, development, ecology and women's rights, and has since been building and consolidating stable networks (Pellow, 2007; Pianta \& Marchetti 2007). Likewise, the Zapatista movement, which initially began on January 1, 1994, is well known for fostering economic and political support through its grassroots struggles for autonomy and contestations against the Mexican government, for condemning the hunger, poverty, and lack of democratic institutions available to indigenous and other communities in the Mexican Republic and elsewhere, and for politicizing activists' interconnected grievances primarily against neoliberalism (see Andrews, 2011, p. 139). These transnational forms of activism draw our attention to particular forms of contested knowledge about state and international institutional support for neoliberal agendas, to the diverse identities or subjectivities of the network of activists involved, and to grassroots demands for social justice and social change.

In addition to grassroots forms of transnational activism, there are transnational activist organizations that address a wide spectrum of social justice issues which extend beyond the territory of a state, such as those ranging from demands for fair trade, fair treatment, and human rights for vulnerable groups, to the eradication of poverty, violence against women, and authoritarian forms of rule. Such forms of activism frequently engage in diverse struggles that can push social justice demands for human, migrant, and citizenship rights, gender equity relations, and sustainable public health, housing, and education rights and services to the transnational community agenda, despite conflicting pressures from certain states, private agencies, and international organizations (Basok \& Ilcan, 2013; Ilcan 2013a). These struggles involve equally diverse agendas, goals, and movement tactics. Concurrent to transnational struggles for social justice are those movements that seek to exclude and define the social and political community in limiting and exclusionary ways, such as antigay or racist, xenophobic activism. In general, political participation in these and other similar forms of transnational activism is increasingly enhanced by information and communication technologies (ICTs) through, for example, quicker interaction, the sharing of strategies and information across massive distances, and the low costs of interactive communication (see Bennett, Breunig, \& Givens, 2008; Gillan \& Pickerill, 2008). But Gillan and Pickerill (2008) also emphasize that activists have revealed concerns regarding uneven accessibility, surveillance, enigmatic and diffuse audiences, and difficulties in building trust online.

Given the diversity of goals, approaches, and political identities of the 
participants involved, transnational activism cannot be easily understood in comparable or equivalent terms. Rather, it is influenced by the actions and engagements of specific kinds of participants, by the orientations and perspectives that guide the demand for future social, economic, and political transformations, and by the successes, challenges, and limitations that characterize its forms. For example, No Borders - which emerged in 1999 with the aim of connecting pro-migrant and anti-capitalism protests against restrictive border controls, anti-migrant policies, and deportations-is an expanding coalition of diverse grassroots groups (anarchists, feminists, civil liberties groups, and migrant and refugee organizations) that works to interconnect people from different political practices and with different regional experiences (No Borders, 2011). From our perspective, it is crucial to consider the historical, social, and political conditions that shape transnational forms of activism, that raise social justice questions about state and international practices and policies, and that foster rhizomatic links to other anticipated contestations, forms of knowledge, and everyday transformations (see also Ilcan, 2013b; Lacey, 2013).

The articles in this Special Issue on Transnational Activism alert us to how transnational activism and struggles can involve different local, regional, national, transnational, and international activities that are fluid and characterized by varying network groups, agencies, and organizations that cannot be simply territorialized at the level of the nation state. In the first article on struggles against bilateral free trade agreements (FTAs), Aziz Choudry explores the apparent disconnect between Northern movements against global and regional free trade negotiations, such as through the World Trade Organization, and Southern struggles against specific free trade agreements. He argues that a wide range of localized resistance movements have countered ongoing and specific trade agreements, including in South Korea, Central American Free Trade Agreement countries (Costa Rica, Honduras, Nicaragua, El Salvador and Guatemala, and the Dominican Republic), Ecuador and Thailand, but with little attention from or engagement with transnational global justice activism. Choudry contends that the successes (and sometimes lack thereof) and modes of activism arising from these mainly Southern struggles could inform both global justice movements' practice and thinking and dominant scholarly and movements' conceptions of global justice. His analysis calls for greater attention from the North to the South, recognizing that connections are slowly forming between South-based anti-FTA activists and that these social movements are vitally producing and sharing knowledge pertinent to the struggles against global capitalism.

This role of networks is highlighted by Luisa Veronis in her examination of the role of non-profit sector networks in contributing to immigrant political participation. Specifically, Veronis explores the potentials and limits of the Hispanic Development Council's (HDC) networks at the community, city, and transnational levels. This Council serves as an umbrella advocacy organization for agencies assisting Latin American immigrants in Toronto, Canada. The ethnographic study of HDC seeks to address the role of networks 
of immigrant non-governmental organizations (NGOs) and advances the argument that HDC networks demonstrate that advocacy in a context of neoliberal governance is possible. Further, Veronis demonstrates that nonprofit sector NGOs, like HDC, can navigate multiple modes and scales of engagement simultaneously, and that they do not have to choose between a centre, margin, or middle ground position.

Knowledge production and dissemination as power is a central argument of Carol Harrington's article that considers transnational feminist networks. Harrington makes use of social movement and governmentality theories to explore the ways in which transnational or global women's organizations have contributed to knowledge of women as a population category. In the field of development, for example, European and U.S. women's organizations promoted international standards on women's status, producing data and rankings, as a means to include women in global government. Likewise, internationally networked women's organizations have produced knowledge on who is safe, who is insecure, and how women are to be made safe. Harrington provides a rich account of the power of international women's organizations, and she argues that their power lies in production and dissemination of a category for government, that of women as cross border population category.

In a very different focus on women's activism to that provided by Harrington, Liza Mügge presents an analysis of the extent to which Turkish and Kurdish migrant women in the Netherlands have engaged in transnational activism before and after the fall of the Berlin wall. The two women's groups that are the focus of Mügge's study - the Turkish Women's Federation in the Netherlands (HTKB) and the International Free Women's Foundation (IFWF), present unique case-studies of transnational Turkish and Kurdish politics in the Netherlands, which she argues is otherwise almost completely male-dominated. For both groups of women activists, Mügge found that struggles for or concerns with gender equality were distinctly secondary to broader ideological focuses, which stem from political parties in their homelands. While gender remained subordinate as an issue for activism in these two organizations, Mügge argues that after the end of the Cold War, new social justice claims emerged and the groups continue to evolve as their transnational links with the "homeland" also change.

Marcia Oliver's article on transnational antigay activism's interaction with and impact on local dynamics in Uganda offers further insight into the complex relationship between local and transnational activist knowledge transfers. Oliver demonstrates that antigay activism in Uganda is shaped by the politics of the U.S. Christian Right's pro-family agenda as well as local manifestations and interpretations of colonial-inspired notions of "African" sexuality and the increasing impacts of global neoliberalism. Along with post-colonial scholars and activists, Oliver argues that these latter effects are not only manifest in antigay activism but can also inform Northern activists and donors working in defense of gay and lesbian rights, providing vital lessons for social justice activists' engagement with local communities. 
Oliver's contextualized examination of Uganda's Anti-Homosexuality Bill offers awareness into the complex dynamics and expressions of local and transnational antigay activisms. She demonstrates that while the U.S. Christian Right continues to impact antigay discourse and politics in Uganda, these influences are shaped by legacies of colonialism and the flow of capital and inequalities wrought by neoliberal globalization. Moreover, this activism is also shaped by specific local particularities relating to "African" culture and tradition, neo-colonial influence and power, and national sovereignty and identity struggles which in turn present a keen sense of dynamism that belies a simple uni-directional notion of power in transnational activism.

The next article provides a consideration of pro-same-sex marriage and anti-Proposition 8 activism in California, U.S.A. Alexa Degagne examines the activism of three Californian pro-same-sex marriage organizations, Equality California, Join the Impact, and the Courage Campaign. She argues that these organizations adopted, challenged, or appropriated neoliberal and social conservative political rationalities in their strategies to promote greater social inclusion with regard to marriage. She finds that in the course of their campaigns all three organizations espoused certain elements of social conservative and neoliberal political rationalities in order to attempt to gain greater inclusion through same-sex marriage. Degagne highlights the potential dangers of such movement strategies that potentially re-imagine spaces of exclusion. The exploration of these three elements of the "No On Proposition 8" movements is also a pertinent reminder from Degagne that the politics and movement tactics of the three organizations highlights the diverse politics of wider gay, lesbian, bisexual, and transsexual movements.

In the final article, Nandi Bhatia explores social justice-oriented South Asian drama in Canada. Bhatia examines the dramas' use of notions of home of origin to portray and bring to the fore issues of social justice and discrimination. She argues that this type of South Asian drama serves as a vital art form for diaspora and non-diaspora as it provides a social text on rightsbased struggles. South Asian Drama therefore acts as political movement; its producers, participants, and audiences simultaneously produce and are introduced to new ideas of the homeland, as well as the new home, and social justice enacted in these spaces.

This volume's contributions provide compelling evidence that it is critical to consider how various forms of transnational activism can produce short or long-term change, contribute to new forms of knowledge and knowledge mobility, offer the potential for enlarging the social and political spaces of transnational activism, locally and globally, and raise questions about the role of powerful organizations and states in these and other similar processes (see also Lacey, 2005; Olesen, 2011; Routledge \& Cumbers, 2009).

Continued research is needed on transnational activism to show how different forms of activism at the local, national, and international level are activated, how connections and fissures are created within and across groups and organizations, and how activist networks, agencies, and organizations are enlisted and how they imagine their efforts towards attaining social justice 
and social change. These and other related issues can be fruitfully explored through the expanding, interdisciplinary research that is currently being conducted on this theme, including the articles in this special issue. Although outwardly diverse, the seven articles in this volume examine how various forms of transnational activism aim towards bringing about a more sociallyjust world and, equally, how vital it is to understand those that do not. These articles contribute to understanding the complexity of movement organizing and knowledge production across transnational social and political space, as well as the widely varied instrumental and less recognizable impacts of movements for change. It is our hope that these contributions will inspire further debates.

\section{References}

Andrews, A. (2011). How activists "take Zapatismo home": South-to-north dynamics in transnational social movements. Latin American Perspectives, 176(38), 138-152.

Basok, T. \& Ilcan, S. (2013). Issues in social justice: Citizenship and transnational struggles. Toronto: Oxford University Press.

Bennett, W. L., Breunig, C., \& Givens, T. (2008). Communication and political mobilization: Digital media and the organization of anti-Iraq war demonstrations in the US. Political Communication, 25, 269-289.

Gill, S. (2000). Towards a postmodern prince? The battle of Seattle as a moment in the new politics of globalisation. Millennium, 29(1) 131-140.

Gillan, K. \& Pickerill, J. (2008). Transnational anti-war activism: Solidarity, diversity and the internet in Australia, Britain and the United States after 9/11. Australian Journal of Political Science, 43(1) 59-78.

Hadden, J. \& Tarrow, S. (2007). The global justice movement in the United States since Seattle. In D. Della Porta (Ed.), The Global Justice Movement. Cross-National and Transnational Perspectives (pp. 210-231). Boulder, CO: Paradigm Publications.

Ilcan, S. (Ed.). (2013a). Mobilities, knowledge and social justice. Montreal and London: McGillQueen's University Press.

Ilcan, S. (2013b). Paradoxes of humanitarian aid: Mobile populations, biopolitical knowledge, and acts of social justice in Osire Refugee Camp." In S. Ilcan, (Ed.), Mobilities, knowledge and social justice. Montreal and London: McGill-Queen's University Press. In Press

Klein, N. (2002). Fences and windows. Dispatches from the front lines of the globalization debate. London: Flamingo.

Lacey, A. (2013). Symbolic knowledge mobilities and biopolitical governmentalities of resistance of Soloman Islands' Pipol Fastaem. In S. Ilcan, (Ed.), Mobilities, knowledge and social justice. Montreal and London: McGill-Queen's University Press. In press.

Lacey, A. (2005). Spaces of justice: The social divine of global anti-capital activists' sites of resistance. Canadian Review of Sociology and Anthropology, 42(4) 403-20.

No Borders. (2011). Homepage. Retrieved from http://www.noborder.org/iom/

Olesen, T. (2011). Introduction. In T. Olesen, (Ed.), Power and transnational activism (pp. 1-20). London and New York: Routledge.

Pellow, D. N. (2007). Resisting global toxins: Transnational movements for environmental justice. Cambridge, MA: MIT Press.

Pianta, M. \& Marchetti, R. (2007). Global justice movements. The transnational dimension. In D. Della Porta (Ed.), The global justice movement. Cross-national and transnational perspectives, (pp. 29-51). Boulder, CO: Paradigm Publications.

Routledge, P. \& Cumbers, A. (2009). Global justice networks: Geographies of transnational solidarity. Manchester and New York: Manchester University Press. 